\title{
Antioxidant Capacity Assay and Sensory Evaluation of Flavored Healthy Snack Composed from Nori of Green Grass Tree Leaves (Premna Oblongifolia Merr.)
}

\author{
Budi Wibowotomo $^{1}$ Laili Hidayati $^{2}$ Susi Devi Hariyani ${ }^{3}$ \\ ${ }^{1,2,3}$ Department of Industrial Technology, Faculty of Engineering, Universitas Negeri Malang \\ "Corresponding Author, Email: budi.wibowotomo.ft@um.ac.id
}

\begin{abstract}
Nori is a popular Japan traditional food made from Red seaweeds and has unique characteristic is a crispy texture. In this research, Nori sheets was developed into flavored snack food, which are added with basic seasoning by different coating technique (greasing, dyeing, spraying) before dried with baking technique. The research aims to observe effect of different seasoning coating (greasing, dyeing, spraying) to the antioxidant capacity and organoleptic properties (color, texture, flavor) of flavored healthy snack composed from Nori of green grass tree leaves (Premna Oblongifolia Merr.). Data was analyzed using ANOVA and DMRT as subsequent test. Results showed that the IC50 of greasing was $95.367 \mathrm{ppm}$, dyeing was 80.905 , and spray was $130.062 \mathrm{ppm}$. The difference of antioxidant capacity is due to the less existed condiment in the nori juice of grass green leaves, lowering capacity of antioxidants. There is no difference in hedonik quality of texture of green grass leaves, and the highest score is of 4.09 (pretty crisp - crispy) on brushing. There is the highest score in hedonik qulity of taste of 4.26 (pretty tasty-tasty) on dyeing. There is the highest score hedonik the color of green grass leaves nori snack tree on dyeing with a score of 4.06. This score was significantly in contrast with brushing and spraying technique. The hedonik of texture showed no difference, with the highest score is on dyeing by of 4.26. The hedonik of taste showed significant difference among coating techniques, with the highest score found in brushing by of 4.10. Some suggestions are proposed to develop a snack of green grass tree leaves nori as healthy snacks, and further research to investigate the broken power of healthy snack composed from nori of green grass leaves, as well as its related water content.
\end{abstract}

Keywords: nori, healthy snack, coating technique, antioxidant capacity

\section{PRELIMINARY}

Noriis a traditional food that is consumed after being dried and baked (Riding et al., 2004 in Teddy, 2009). Nori came from Japan with the raw material of red seaweed Porphyra species. Nori is a food that has a high nutritional value, it is the primary reason why nori widely produced and consumed in Japan, China and Korea produce nori with a total production reached 2 billion pieces per year (Department of Marine and Fisheries2007).

Nori-making process through the process of forming a gel that is formed by the gel-forming component (KPG) of seaweed. The gel is formed in the manufacture of nori obtained from the cooking processseaweed to issue a gel (Teddy, 2009). One of the plants that can form a gel is green grass jelly plant trees.

Results Basuki (2016), shows that the nori leaf tree with green grass jelly grass jelly leaf ratio of green trees and water of 1: 5 to have antioxidant capacity with IC50 values were higher than the 1:10 ratio and the ratio of $1: 15$.

Results Nurzaman (2016), shows that the ratio used is the ratio of green grass jelly leaves of trees and water 1:10 because the closest characteristics of nori with drying 3 hours. Nori leaf tree with long green grass jelly drying for 3 hours had a higher antioxidant capacity than the old drying for 4 hours and 5 hours with IC50 value of $79.858 \mathrm{ppm}$.

Nori used as a garnish and flavoring a wide variety of Japanese dishes, side dishes when eating rice, and materials snacks as Senbei(Teddy, 2009). In addition, nori many found on the market as a healthy snack that many kids love. In Indonesia, nori much needed especially in restaurants serving Japanese and Chinese dishes using nori. Nori is consumed today is imported from Japan, Korea, China and the United States.

Based on the above background, it is necessary to develop the manufacturing healthy snack nori is the result of the development of the results of the nori sheet of green grass jelly leaf trees that have been dried by the provision of seasoning and roasting so that it can be consumed as snacks that taste. Besides products that have health effects because it contains the antioxidant capacity of green grass jelly leaf trees and white seasoning.

Many note that the formula of seasoning in nori seaweed snack disupermarket or average market using basic materials sesame oil and salt, and therefore the processing of toasted nori snack spice white base formula with different 
techniques. The technique used is the technique of topical, dip and spray. Selecting these three techniques because they want to know the proper techniques of the different spices of nori snack market. Therefore do research titled "Antioxidant Capacity Analysis and Test Appearance Seasoned Nori Snack Cincau Green Leaves Trees (Premna oblongifolia Merr.).

\section{METHOD}

Material. Raw materials used for the manufacture of snack nori in this peelitian is a sheet of nori leaf green grass jelly and seasoning tree white powder. Besides using the three techniques of seasoning which dye technique, technique and technique topical spray.

Nori manufacture Cincau Leaf Green.The process of making nori leaf green grass jelly grass jelly begins with sorting green leaves, removal of bone leaves and wash thoroughly. Leaf green grass jelly further crushed using a blender and extracted using water at room temperature. The ratio of water to the leaf that is used is 10: 1, w / w. Extract the resulting molded using a mold nori (pan) size $30 \mathrm{~cm} \mathrm{x} 40$ $\mathrm{cm}$ that had been given filter cloth pads. The next process is drying at a temperature of $45-50{ }^{\circ} \mathrm{C}$ in a drying oven for 3 hours.

Making the Basic Seasoning White. Formula basic white seasoning consisting of onions, garlic, nutmeg, coriander, pepper grains, salt, oil and water. All the ingredients in a blender together and cooked for 15 minutes, after which it was dried using a drying oven for 2 hours.

Nori Snack manufacture Cincau Leaf Green Tree. Snack nori used is nori leaf green grass jelly trees measuring $30 \mathrm{x}$ $40 \mathrm{~cm}$ with a weight of 4 grams. Nori size is flavored with three different techniques

Oles techniques. technique Award This seasoning is done with the technique applied to the nori leaf tree green grass jelly. Method of administration pectin $2 \mathrm{~g}$ of white mixed with herbs $3 \mathrm{~g}$ dissolved in water to $12 \mathrm{ml}$. Rub seasoning at $1 / 2(2 \mathrm{~g})$ sheets of nori leaf tree green grass jelly. Once applied the green grass jelly leaf nori let stand for 5 minutes tree, roasted nori leaf tree with green grass jelly $110 \mathrm{oC}$ temperature for 7 minutes.
Dye Techniques. Techniques of this condiment made with nori dipped in seasoning. Method of administration pectin 2 $\mathrm{g}$ of white mixed with herbs $3 \mathrm{~g}$ dissolved in water to $12 \mathrm{ml}$. Enter $1 / 2(2 \mathrm{~g})$ sheets of nori leaf tree green grass jelly, grass jelly leaf green nori let stand for 5 minutes tree. Toasted nori leaf tree with green grass jelly $110 \mathrm{oC}$ temperature for 7 minutes.

Spray Technique. Techniques of this condiment made with nori sprayed with white seasoning. Nori used is $1 / 2(2 \mathrm{~g})$ sheets of nori. Nori leaves green grass jelly smeared tree pectin $2 \mathrm{~g}$. After nori leaf tree green grass jelly smeared with pectin, nori green grass jelly leaf trees sprayed with white seasoning 3 grams dissolved in $12 \mathrm{ml}$ of water. Nori green grass jelly leaves of trees allowed to stand for 5 minutes and then baked at a temperature of $110 \mathrm{oC}$ for 7 minutes.

Antioxidant Capacity Analysis. Nori snack antioxidant capacity was determined by DPPH method. This method is a method sderhana, fast and easy to screen multiple compounds radical trapping capacity, other than that this method proved to be accurate, effective and practical (Molyneux, 2003).

Appearance test.Analysis is conducted test hedonic quality (texture and flavor) and hedonic test (color, texture and flavor). The hedonic quality test texture 1 (not crispy) - 5 (crunchy). The hedonic quality test taste 1 (not savory) - 5 (savory). The hedonic test with a score of 1 (dislike) - 5 (love). Panelists used are student State University of Malang as many as 35 people with two repetitions.

Statistic analysis.Research data from two repetitions were statistically analyzed using ANOVA (Analysis of Variance) to determine the effect of treatment. If there is a difference between samples, analyzed its significance $(\mathrm{p}<0.05)$ using the Duncan Multiple (Duncan's Multiple Range Test).

\section{RESULTS AND DISCUSSION}

\section{a) Antioxidant Capacity}

Value of antioxidant capacity of green grass jelly snack nori leaf trees that have a high value are techniques of dyeing to 80.905 ppm (Table 1). Because seasoning stick on green grass jelly snack nori leaf tree more pervasive and content of antioxidant capacity in more seasoning deep full on green grass jelly snack nori leaf trees.

Table 1. Antioxidant capacity of snack nori composed from green grass tree leaves $\left(\left(\mathrm{IC}_{50}, \mathrm{ppm}\right)\right.$

\begin{tabular}{lccc}
\hline \multirow{2}{*}{ Technique } & \multicolumn{2}{c}{ Replication } & Average \\
\cline { 2 - 3 } & I & II & \\
\hline Dyeing & 81,644 & 80,167 & 80,905 \\
Greasing & 96,107 & 94,628 & 95,367 \\
Spraying & 130,062 & 129,568 & 129,815 \\
\hline
\end{tabular}

\section{b) Hedonic quality test of texture}

The hedonic quality test (Fig 1) of texture highest are techniques of seasoning dip with a score of 4.26 (quite crispy - crunchy), because according to Riyanto et al (2014), commercial nori have the rough texture, resembling a dark green colored paper and with a size of $10 \times 19 \mathrm{~cm}$ and weighs 2.8 grams. 


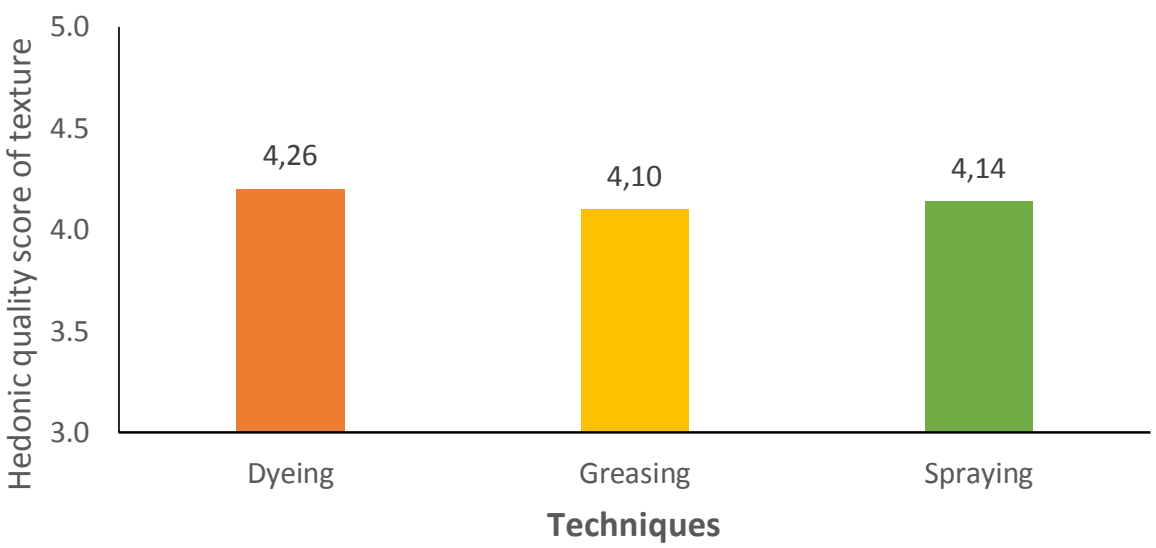

Fig 1. Hedonic quality score of texture of snack nori composed from green grass tree leaves

c) Hedonic quality test flavor

The hedonic quality test flavor of snack nori green grass jelly leaves of tall trees (Fig 2) was found in topical technique has a score of 4.09 (enough - savory), because the nori snack products in general have a taste salty and savory (Syarifah, 2016).

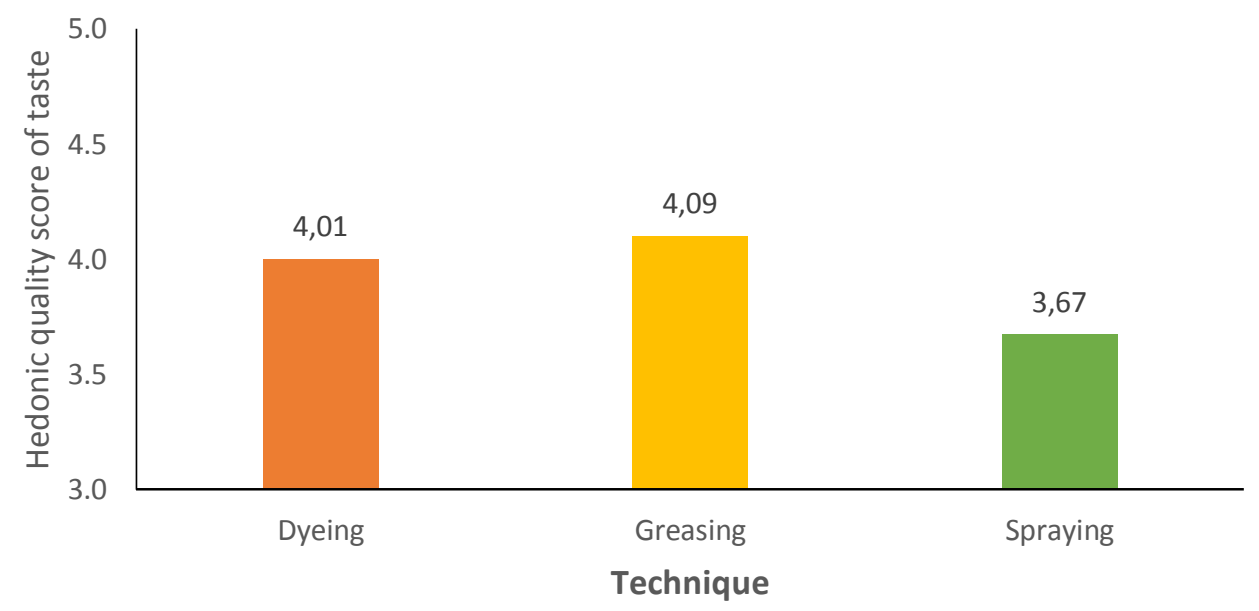

Fig 2. Hedonic quality score of taste of snack nori composed from green grass tree leaves

\section{d) Hedonic score of color}

Based on the hedonic score of color (Fig 3) can be seen that the green grass jelly snack nori leaf trees tend to be preferred by the panelists are techniques of seasoning dip with a mean score of 4.06 (rather like - likes). The color of green grass jelly snack nori leaf panelists preferred tree is not too brown. 


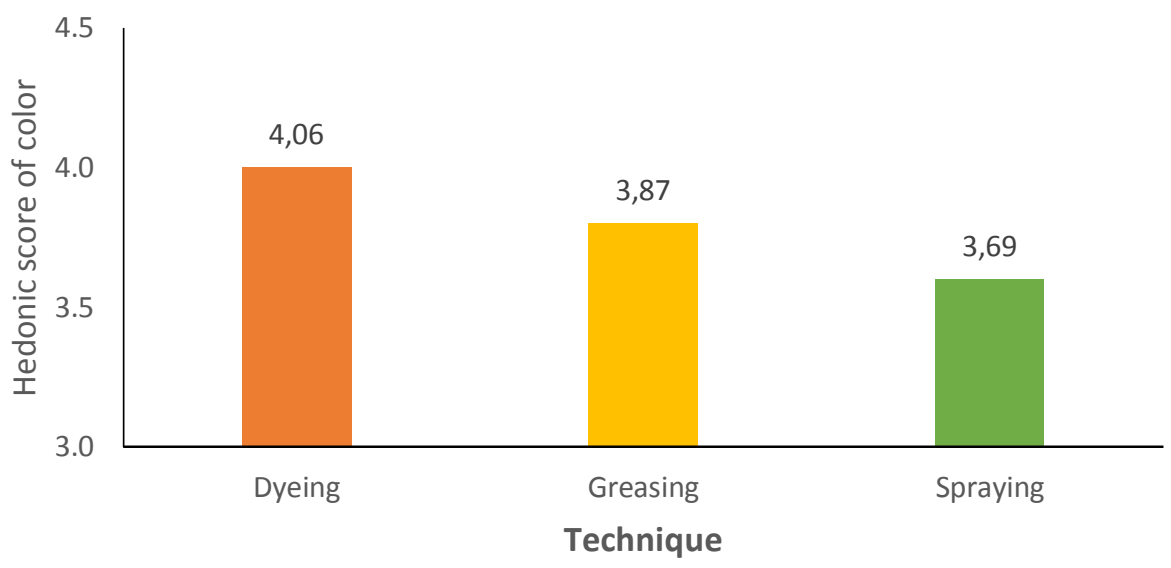

Fig 3. Hedonic score of color of snack nori composed from green grass tree leaves

\section{e) Hedonic score of texture}

Texture of green grass jelly snack nori leaf tree (Fig 4) with seasoning topical delivery techniques have the lowest level of preference 4,10 (rather like it - like it) because it has a rough texture and seasoning sticks to snack nori leaf green grass jelly thicker tree resulting texture rough compared with green grass jelly snack nori leaf tree with other herbs delivery techniques.

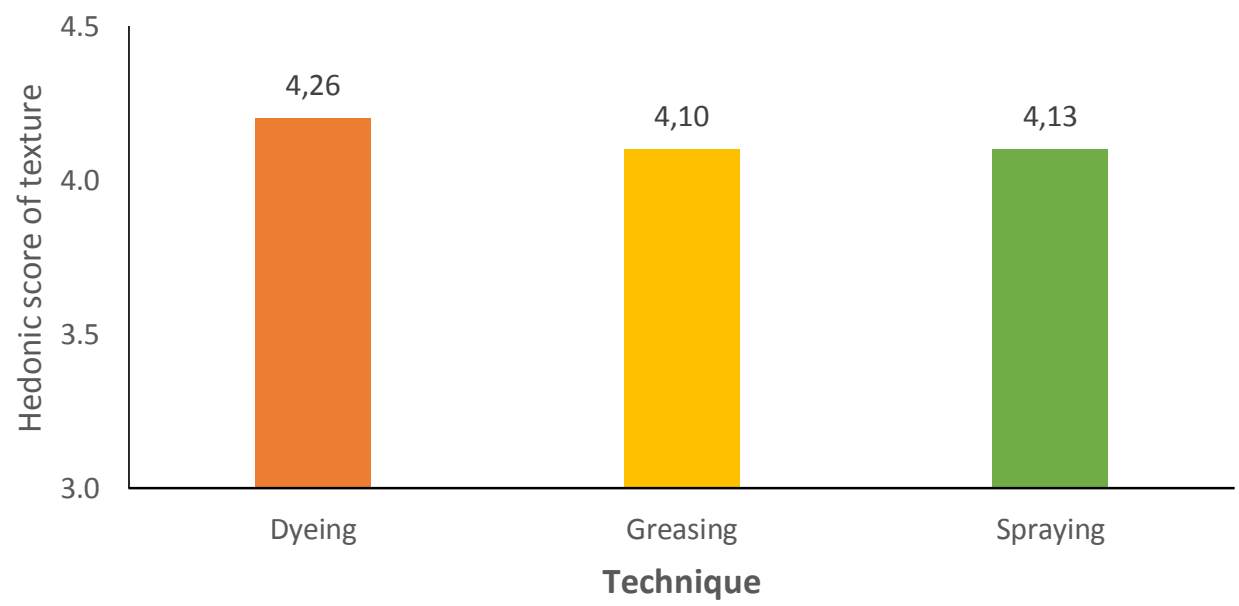

Fig 4. Hedonic score of texture of snack nori composed from green grass tree leaves

f) Hedonic score of taste

Based on the hedonic taste test (Fig 5) showed that green grass jelly snack nori leaf trees tend preferred by the panelists, namely snack nori leaf tree with green grass jelly techniques of seasoning rub with a mean score of 4.10 (rather like - likes). 


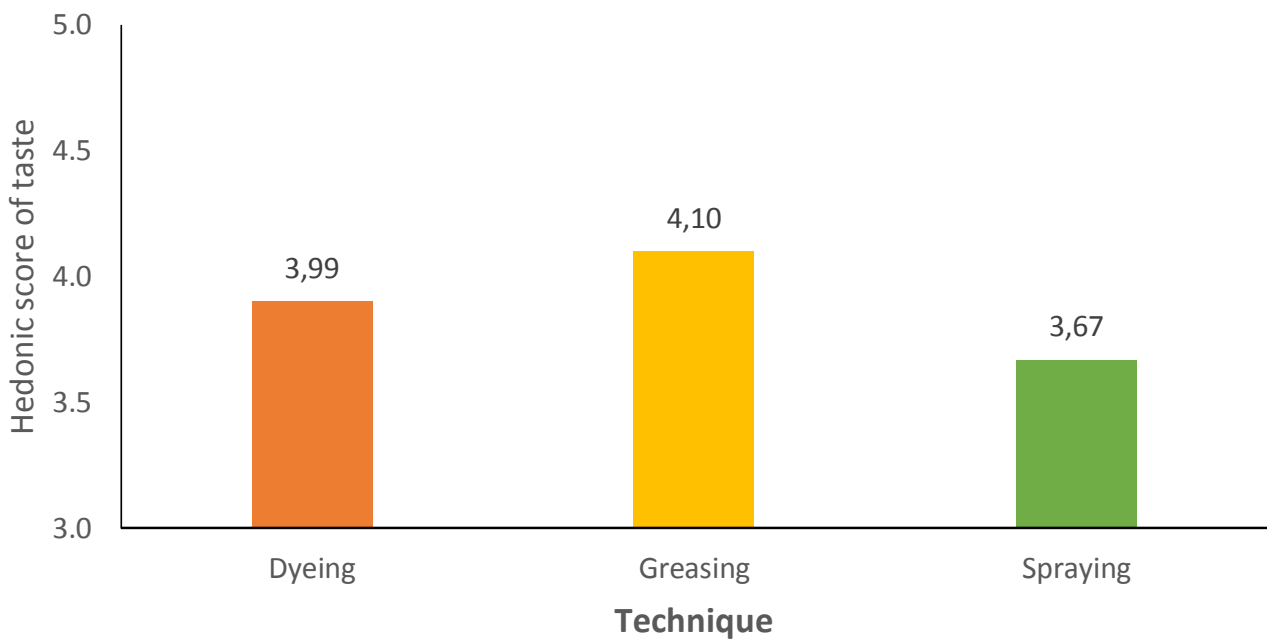

Fig 5. Hedonic score of taste of snack nori composed from green grass tree leaves

\section{IV.CONCLUSION}

The highest antioxidant capacity to the nori snack tree leaves green grass jelly contained in the techniques of seasoning dip with ic50 amounted to $80.905 \mathrm{ppm}$. Hedonic quality properties value at the highest texture nori snack tree leaves green grass jelly contained in the techniques of seasoning dip with a mean value of 4.26 (quite tasteful savory). Hedonic quality properties value at the highest sense of green grass jelly snack nori leaf tree found in the condiment topical delivery techniques with 4,09 (quite tasteful - savory). Values hedonic properties of the highest color on green grass jelly snack nori leaf tree found in the condiment delivery techniques dye with a mean value of 4.06. Values hedonic properties of the highest texture on green grass jelly snack nori leaf tree found in the condiment delivery techniques dye with a mean value 4,26. Hedonic property values in the highest sense of nori snack tree leaves green grass jelly contained in the seasoning topical administration with a mean value of 4.10 . Best technique award at the snack seasoning nori leaf tree is green grass jelly seasoning techniques of dyeing with the characteristics of the antioxidant capacity of 80.905 ppm. 4.26 hedonic quality nature texture (crunchy enough), the nature of the hedonic quality of taste 4.09 (crispy enough). Hedonic properties of color 4.6 (a bit like - like), hedonic properties of texture 4.

\section{REFERENCES}

[1] Amarowicz, R., Naczk, M., Shahidi, F., 2000. Antioxidant Activity of Crude Tannins of Canola and Rapeseed Hulls. Journal of the American Oil Chemists' Society, 77, 957-961. (On line). https://link.springer.com/article/10.1007/s1174 6-000-0151-0, accessed on January 1, 2017.

[2] Astawan, M. 2006. Functional Food for Optimal Health. (Online) http://www.kompas.com/kesehatan/news/0501 / 16/22033.

[3] Ayustaningwarno, F. 2014. Food Technology Practical Theory and Applications. Semarang: Graha Science.

[4] Basuki, YT 2016.Pengaruh Leaf Ratio and Water Against Physicochemical properties and Quality Appearance Cincau Nori Leaf Green Tree (Premna oblongifolia Merr.). Essay. Department of Industrial Technology, Faculty of Engineering, University of Malang.

[5] Bayan, L., Koulivand, P., A. Gorji 2013. Garlic: a review of potential therapeutic effects. Avicenna Journal Phytomed. 4 (1): 7 21

[6] Chalid, SY 2002. "Effect of Green Cincau Leaves (cyclea barbata L. Miers and Premna obliongofilia Merr) Extracts on Antioxidant Activity and Tumor Growth of Mammary Gland of Transplantable Mice. Master Thesis. Bogor. Bogor Agricultural Institute. http://journal.uinjkt.ac.id/index.php/valensi/art icle/view/212), accessed on October 20, 2017.

[7] Daraoni, OS 2006. Assessment Process of Mixed Herbal Tea Green Tea (Camellia sinensis), Rhizome Bangle (Zingiber cassumunar Roxb.) And leaves Ceremai (Phyllanthus acidus (L.) Skeels.). Unpublished thesis. Bogor: FTP IPB. (Online) https://respository.ipb.ac.id/handle/123456789 13740, accessed on October 6, 2017.

[8] [DKP] Department of Marine and Fisheries. 2007. Seaweed. Department of Marine and Fisheries.

[9] FAO. 2008. FAO Rice Market Monitor 11 (2). Rome. 
[10] Farrell, KT 1990. Spices, Condiments, and Seasoning. Second Editiion. Van Nostrand Reinhold. New York.

[11] Gim-Gui. 2014 or Toasted Roasted Seaweed Snacks (Gim). (On line)file: /// H: / Roasted or Toasted Seaweed Snacks (Gim) Chow Chow Divine ... Divine A6.html, accessed on 14 April 2017.

[12] Harvelly., Nurminabari, SI, Grace, DN 2016. Effect of Drying Method and Condiments Against Granting Characteristics Minced Fish Fillet Tuna (Euthynnus affinis). (Online) http://repository.unpas.ac.id/26607/1/ARTIKE L\%20Nadya\%20Dwi\%20Anugrah_12302006 8.pdf, accessed on 15 November 2017.

[13] Ihsan, F. 2016. Utilization Kolang Making Nori With fro as Material substitution Seaweed Eucheuma cottonii type. https://scholar.unand.ac.id/17791/8/Skripsi\%2 0Utuh.pdf, accessed on November 3, 2017.

[14] Irfan, M. 2013. Response of onion (Allium ascalonicum $\mathrm{L}$ ) on the plant growth regulator and Nutrients. (Online) https: // ejournal.uinsuska.ac.id/index.php/agroteknologi/article/vie w/86, accessed on January 1, 2018.

[15] Ismail, A., and Hong, TS 2002. Antioxidant Activity of Selected Commercial Seaweeds. Malays Journal of Nutrition., 8 (2), 167-177.

[16] Jacubczyk., Gondek, E., Antoniuk, A., Gerello, A., Walczuk, J. 2013. Analysis of Texture of Extruded Cereal Products with Filling. Inside Food Symposium Leuven, Belgium.

[17] Jilani. 2007. Efficacy of Shallot. Yogyakarta: Canisius, 2007. 16-26.

[18] Jun, M, HY, Fu, J., Hong, XX, Wan, CS Yang., C. Ho. 2006. Comparison of Antioxidant Activities of isoflavones from Kudzu Root (Pueraria Iobateohwi). The Journal of Food Seciene, (Online), 68 (6): 2117 $-2122$. https://www.researchgate.net/publication/2297 31731_Comparision_of_Antioxidant_Activitie s_of_Isoflavones_from_Kudzu_Root_Pueraria _lobata_Ohwi\#fft, accessed on October 6, 2017.

[19] Kim, MY, Choi SW., SK Chung. 2002. antioxidative Lavonoids from The Garlic (Allium sativum L.) Shoot. Food Science and Biotechnology 9 (4): 199-203.

[20] Korringa, P. 1976. Farming Marine Organism Low In The Food Chain. Amsterdam, Oxford, New York: Elsevier Scientific Publishing Company.

[21] Horse, T., Makiko T., Hishi T., Araki Y. 2004. Antioxidant Properties of Dried "kayamo-nori" a Brown Algae Scytosiphon Lomentaria
Scytosiphonales, Vinogradova. Journal Food Chemistry. 89: 617-622

[22] Kuntorini, E and Astuti, M. 2013. Determination of Antioxidant Activity of Ethanol Extracts Garlic Bulbus Dayak (Eleutherine Americana Merr.). Science and Applied Chemistry, (Online), 4 (1): 15-22, (http://download.potalgaruda.org/ article.php? Article $=111611 \&$ val $=5160$ ), accessed on May 29, 2017.

[23] Kurnianingsih, F. 2013. Comparative Antioxidant Power Herbs and Herbal Turmeric Turmeric Instant Asam Asam Fresh Herb Method with 2,2-diphenyl-1-pikrihidrazil (DPPH), unpublished thesis. Yogyakarta: Ffarm Sanata Dharma (Online) http://repository.usd.ac.id/5229/, accessed on October 6, 2017.

[24] Lasmanawati and Yulia, 2012. Influence of Nutrition Course Based On Student Selection Snacks Food Catering Education Program. Unpublished thesis. Indonesian education university. (Online) https://ejournal.upi.edu/index.php/Boga/article /download/6407/4378, accessed on November 3, 2017.

[25] Mardiah.,Frances RZ, Lia AT, 2007. Anticancer food. Jakarta: Kawan Pusataka.

[26] Molyneux, P. 2003. The Use of The Stable Free Radical Diphenylpicrylhydrazyl (DPPH) for Estimating Antioxidant Activity. Journal of Science of Technology. 26 (2): 211-219.

[27] Nawangsari, D., Setyarini, I., Nugroho, P. 2008. Utilization of Onion (Allium cepa L.) As Ko-Chemotherapy Agents. Student Writing. Faculty of Pharmacy. Gadjah Mada University. (Online) https: // www. Utilization + onions + Red +\% 28Allium + cepa + L\% 29 + as + Agent + KoKemoterapi $+\&$ oq $=$ Utilization + onions + Red +\% 28Allium + cepa + L\% $29+$ as + Agent + KoKemoterapi + \& gs, accessed on January 012018.

[28] Nuraini. Practical Hints 2013. Sensory Evaluation. Purwokerto. Study Program Food Science and Technology.

[29] Nurdin, SU and US Suharyono 2007. Functional Characteristics of Polysaccharides Sculpting Gel Cincau Leaf Green (Premna oblongifolia Merr.) (Online)http://uppmpolinela.files.wordpress.co $\mathrm{m} / 2008 / 07 /$ karakteristikfungsional

polysaccharide-gel-forming leaf-grass jellyhijau.doc, Accessed on 1 April 2017.

[30] Nurdin, Kusharto, CM, Tanziha, I., Januwati. 2009. Content of Chlorophyll Different Types of Plant Leaves and Cu-Chlorophyll Derivatives And Physico-chemical 
characteristics. Journal of Nutrition and Food 4 (1): 13-19.

[31] Nurzaman, A. 2016. Influence of Drying Against Old Physicochemical and Organoleptic properties Cincau Nori Leaf Green Tree (Premna oblongifolia Merr.). Unpublished thesis. Malang: The Malang State University.

[32] Paula, AM and Conti-Silva, AC 2014. Texture Profile and Correlation Between Sensory and Instrumental Analyzes on Extruded Snacks. Journal of Food Engineering 121: 9-14.

[33] Pitojo, S. and Zumiyati. 2005. Cincau: Making and Variations processed. Tangerang. PT. Agro Media Library.

[34] Prakash, A. 2001. Antioxidant Activity. Analytical Laboratory Medallion Progress.

[35] Prasetyowati., Sari, PK, Pesantri, H. 2009. Extraction Pectin Mango skin. jtk.unsri.ac.id/index.php/jtk/article/viewFile/93 /92. Retrieved on October 25, 2017.

[36] Princess. A, F, 2011. Influence of Profitability, Liquidity, Growth and Dividend Policy Against Cash Position. Skiripsi not publish. Degree Program Faculty of Economics, University of Widyatama Bandung. http://repository.widyatama.ac.id/ xmlui/bitstream/handle/123456789/2407/Skrip si\%20Mutiara\%20Putri\%20-

$\%$ 2002.08.244.pdf?sequence $=1$, accessed on November 3, 2017.

[37] Raharjo. 2001. Assessment Appearance. Jakarta: Bharata Works Script.

[38] Rahmawati. 2016. Effect of Addition Comparison Lama Leaves katuk and Nori Fruit Drying Characteristics Of Bananas (Musa paradisiaca formatypica). (Online) repository.unpas.ac.id/10694/2/Artikel\%20Tu gas\%20Akhir.pdf, accessed on November 3, 2017.

[39] Ratnasari, AP 2016. Effect Concentration Against aktvitas Beluntas Leaf Extract Antioxidant, Physical properties, and the properties Appearance Dawet Beluntas. Unpublished thesis. Malang: FT University of Malang.

[40] Riyanto, B., Trilaksani, W., Susyiana, LE 2014. Nori Imitation Gazette Concepts With Protein-Based Edible Film Myofibrillar Tilapia. Journal of Fisheries. Vol. 17 No. 3.

[41] Salat, H. 2009. The Beauty Of Nori. (Online) savour.com, accessed on 14 April 2017.

[42] Sari, YN 2012. Antioxidant activity Extracts and fractions of Cincau Leaf Green (Premna oblongifolia Merr.) With Spectrophotometric Method Using Reagent 1,1-Diphenyl-2- picrylhydrazyl. Unpublished thesis. Jatinangor: Faculty of Pharmacy, University of Padjadjaran.http://kandaga.unpad.ac.id/ Search/Results?type=AllFields\&sort=title \&pa ge $=7 \&$ filter[]=format $\% 3 \mathrm{~A} \% 22$ PeerReview $\% 2$ 2\&filter[]=topic_facet $\% 3 \mathrm{~A} \% 22 \mathrm{Abstrak} \% 22$, accessed on November 3, 2017.

[43] Soewitomo, S. 2007. Basic White Dish Seasoning. Jakarta: PT. Gramedia Pustaka Utama.

[44] Setyaningsih, D. 2010. Sensory Analysis of Food and Agro Industries. IPB Press: Bogor.

[45] [ISO] Indonesian National Standard. 2000. Quality Snack extrudate. Jakarta: PT. Gramedia Pustaka Utama.

[46] Sunanto, H. 1995. Cultivation Cincau. Yogyakarta: Canisius.

[47] Sunaryo, M. 2006. Studying the Effect of Water Content Of Quality Characteristics And Waste Minimization During Taro Snack Net Production Process In Pt. Top Quality taste, Bogor. Unpublished thesis. Bogor: Faculty of Agricultural Technology. (Online) http://repository.ipb.ac.id/handle/123456789/3 729, accessed on November 3, 2017.

[48] Syamsiah, S and Tajudin. 2003. Efficacy and Benefits of Garlic: King of Natural Antibiotics. Jakarta: Agromedia Reader.

[49] Syarifah. 2016. Effect of Concentration of Soybean Meal and Carrageenan Against Characteristics "Snack Nori" Skin of dragon fruit (Hylocereus costaricentus). http://repository.unpas.ac.id/15926/1/ARTIKE L\%20IIS\%20SYARIFAH-123020098.pdf, accessed on November 3, 2017.

[50] Teddy, M. 2009. Making Nori Seaweed Traditionally Of Glacilaria type Sp. Unpublished thesis. Bogor: Faculty of Fisheries and Marine Science IPB. (Online) http: repository.ipb.ac.id/handle/123456789/12772. Accessed on November 3, 2017.

[51] Terramoto, T. 1990. Seaweed, Their Chemistry and Uses. In Science of Processing Marine Food Product. Vol I. Motohiro T, Kaduto H, Hashimoto K, Kayoni M, Tokuraga T, editor. Japan International Center. 142-156. Tsai, TH, Tsai, PJ, and Ho, SC 2005. Antioxidant and Anti-inflammatory Activitiesof Several Commonly Used Spices. Journal of Food Science Vol. 70, Nr. 1, C93. (On line)https://www.google.com/search?clientAntioxidant+and+Antiinflammatory+Activitie sof+Several+Commonly+Used+Spices.Journal + of + Food + Science+Vol. $+70 \% 2 \mathrm{C}+\mathrm{Nr} .+1 \%$ 2CC93. \& oq, Accessed on January 1, 2018. 
Tuti, $S$ and Culinary Team Nutrition Foundation. Culinary 2013. Basic Theory. Jakarta: PT. Gramedia Pustaka Utama.

[54] Wayne. 2005. Rural Development. Journal Of Rural Development ISSN. (On line). https://docslide.us/documents/jurnal-

pembangunan-pedesaan.html, accessed on January 1, 2018.

[55] Winarno, FG 2004. Chemistry of Food and Nutrition. Jakarta: PT. Gramedia Pustaka Main.

[56] Yamamoto, Y. 1990. Nori Seaweed. (On line)http://Id.Stashtea.Com/Stash/Nori, Accessed on March 31, 2017.

[57] Yu, L. 2001. Free Radical Scavenging Properties of Conjugated Linolenic Acids. Journal Argricultural and Food Chemistry. (Online), $49 \quad$ (7): $\quad 3452-3456$, (https://pubs.acs.org/doi/abs/10.1021/jf010172 v), accessed on May 29, 2017.

[58] YUSTINA, I., Nurvia, E., Aniswatul. 2012. Effect of Addition of Various Spices Against Physical Properties, Appearance And passions On Crackers of Fresh Cow Milk. http://pertanian.trunojoyo.ac.id/semnas/wpcontent/uploads/PENGARUHPENAMBAHAN-ANEKA-REMPAHTERHADAP-SIFAT-FISIKORGANOLEPTIK-SERTA-KESUKAANPADA-KERUPUK-DARI-SUSU-SAPI-

SEGAR.pdf, accessed on November 6, 2017.

[59] Zakaria, FR, Priosoeryanto, BP, Erniati., Sajida. 2017. Characteristics of Mixed Nori Seaweed Ulva lactuca and Eucheuma cottani. Journal of Agriculture. (Online) http://bbp4b.litbang.kkp.go.id/jurnal-

jpbkp/index.php/jpbkp/article/viewFile/336/pd f. Accessed on November 3, 2017. 